Research Article

\title{
A comparative study on protective factors, mental health and violence among male adolescents students of urban and rural school of Udaipur (Rajasthan), India
}

\author{
Rajkumari Ahir ${ }^{1}$, Yogesh Kumar Singhal ${ }^{2} *$, Mohan Singh Dhaked ${ }^{3}$, Poornima Sharma ${ }^{4}$
}

\author{
${ }^{1}$ University College of law, Mohan Lal Sukhadia University, Udaipur, Rajasthan, India \\ ${ }^{2}$ Department of Preventive \& Social Medicine, Ravindra Nath Tagore Medical College, Udaipur, Rajasthan, India
}

Received: 22 September 2015

Revised: 22 September 2015

Accepted: 25 September 2015

\author{
*Correspondence: \\ Dr. Yogesh Kumar Singhal, \\ E-mail: yogya_iam@yahoo.co.in
}

Copyright: ( $)$ the author(s), publisher and licensee Medip Academy. This is an open-access article distributed under the terms of the Creative Commons Attribution Non-Commercial License, which permits unrestricted non-commercial use, distribution, and reproduction in any medium, provided the original work is properly cited.

\section{ABSTRACT}

Background: Objective of this study is to compare the prevalence of protective factors, mental health issues, and violence among the urban and rural adolescents.

Methods: A cross-sectional, descriptive study of two months duration was conducted among 280 male students of classes 9th and 10th of one urban and one rural school of Udaipur district of Rajasthan after taking prior permission and consent using a self-administered questionnaire.

Results: Significant observation was identified ( $\mathrm{p}$ value $<0.0001$ ) for missed classes among urban students than rural student $(91.88 \% \mathrm{v} / \mathrm{s} 41.67 \%)$. Parents of urban students are more concerned for their homework $(66.25 \% \mathrm{v} / \mathrm{s} 59.17 \%)$, problems and worries $(63.75 \% \mathrm{v} / \mathrm{s} 58.33 \%)$, and activities in free time $(53.75 \% \mathrm{v} / \mathrm{s} 49.17 \%)$. Mental health issues like loneliness $(13.13 \% \mathrm{v} / \mathrm{s} 10.00 \%)$, worry $(13.75 \% \mathrm{v} / \mathrm{s} 10.83 \%)$, and suicidal thoughts $(9.30 \% \mathrm{v} / \mathrm{s} 6.60 \%)$ were higher among urban students but not significant. Issues on violence and bullying like physical fight $(53.75 \% \mathrm{v} / \mathrm{s} 24.17 \%)$, bullying $(43.15 \% \mathrm{v} / \mathrm{s} 15.0 \%)$, physical attack by family members $(43.13 \% \mathrm{v} / \mathrm{s} 15.83 \%)$, and by teachers $(51.25 \% \mathrm{v} / \mathrm{s}$ $11.67 \%$ ) were significantly higher in urban adolescents ( $\mathrm{p}$ value $<0.0001)$.

Conclusions: Mental health and violence-related issues were prevalent more among urban students than those among rural students in spite of having more protective factors and parents concern suggesting the need of frequent supervision, counselling, monitoring and support of adolescents.

Keywords: Adolescent health problems, Protective factors, Mental health, Bullying, Suicidal thoughts

\section{INTRODUCTION}

Roots for mental health build up reside in the origin of adolescent age. Well thrived adolescents who were enabled with appropriate life skills had a better chance of becoming responsible, intellectual and productive adult, leading to better potentials for leading successfully careers and increased productive and progress. ${ }^{1}$ For most adolescent, school is important setting outside the family. Student's perceptiveness for school environment significantly associated with evolution of their health and wellbeing. ${ }^{2}$ Mental health problems are most common now days among adolescent included anxiety disorder, depression, mood disorders, behavioral and cognitive disorders. Worldwide, four million adolescent attempt suicide annually resulting in at least $1,00,000$ death. $^{3}$ Adolescent children usually face violence in the form of 
verbal abuse, physically handled, bullying by family member, including parents, teachers and fellow student. Victims of bullying suffered mental stress, decrease ability to concentrate and are increases risk of substance abuse, aggressive behavior and suicidal attempts. ${ }^{4}$

Objective of this study is to compare the prevalence of protective factor, mental health issues and violence among adolescents belonging to a rural and an urban senior secondary school of Udaipur district of Rajasthan.

\section{METHODS}

\section{Study setting and design}

Descriptive, cross sectional, school based study was conducted among male adolescent student of urban and rural senior secondary school of Udaipur district. Both schools were selected purposely within RHTC and UHTC area of RNT Medical College Udaipur respectively.

\section{Study population}

One rural school from RHTC and one urban school from UHTC area.

\section{Study duration}

July \& August 2015 (two month)

\section{Method of data collection}

Prior permission was obtained from appropriate authority District Education Officer (Secondary) Udaipur. A questioner was develop following the guideline of core questioner of Global School- based student health survey (GSHS) prepared by WHO, UNESCO, UN,CDC Atlanta and UNICEF in $2001^{5}$.

\section{Inclusion criteria}

(a) school who are willing to participate, (b) the student of classes 9-10 of rural and urban school of Udaipur city, (c) who are present on the day of study, (d) the student who are willing to participate in the study

\section{Exclusion criteria}

Schools and students who are not willing to participate

\section{Methodology for data analysis}

The data collected was entered in excel and analysed statistically using descriptive statistics namely mean, standard deviation, percentage wherever applicable by using software SPSS.

\section{RESULTS}

Table 1: Issues on protective factors.

\begin{tabular}{|c|c|c|c|}
\hline & \multicolumn{2}{|c|}{ Frequencies (\%) } & \multirow[t]{2}{*}{ P Value } \\
\hline & $\begin{array}{l}\text { Urban } \\
\mathrm{n}=160 \\
(57.14 \%)\end{array}$ & $\begin{array}{l}\text { Rural } \\
n=120 \\
(42.86 \%)\end{array}$ & \\
\hline $\begin{array}{l}\text { Missed classes } \\
\text { or school } \\
\text { without } \\
\text { permission }\end{array}$ & $\begin{array}{l}147 \\
(91.88 \%)\end{array}$ & $\begin{array}{l}50 \\
(41.67 \%)\end{array}$ & $<0.0001$ \\
\hline $\begin{array}{l}\text { most of } \\
\text { student in their } \\
\text { school were } \\
\text { kind and } \\
\text { helpful }\end{array}$ & $\begin{array}{l}74 \\
(46.25 \%)\end{array}$ & $55(45.83 \%)$ & 0.944814 \\
\hline $\begin{array}{l}\text { Parents or } \\
\text { guardians } \\
\text { checked to see } \\
\text { If their home } \\
\text { work was } \\
\text { done }\end{array}$ & $\begin{array}{l}106 \\
(66.25 \%)\end{array}$ & $\begin{array}{l}71 \\
(59.17 \%)\end{array}$ & 0.223848 \\
\hline $\begin{array}{l}\text { Parents or } \\
\text { guardians } \\
\text { understood } \\
\text { their problems } \\
\text { and Worries }\end{array}$ & $\begin{array}{l}102 \\
(63.75 \%)\end{array}$ & $\begin{array}{l}70 \\
(58.33 \%)\end{array}$ & 0.3568 \\
\hline $\begin{array}{l}\text { Parents or } \\
\text { guardians } \\
\text { really knew } \\
\text { what they } \\
\text { were doing } \\
\text { with their free } \\
\text { time }\end{array}$ & $\begin{array}{l}86 \\
(53.75 \%)\end{array}$ & $\begin{array}{l}59 \\
(49.17 \%)\end{array}$ & 0.44752 \\
\hline
\end{tabular}

It was observed that $57.14 \%$ and $42.85 \%$ students in the urban and rural schools. Majority of the students $(82 \%$ in urban and $72 \%$ in rural school) belongs to $14-16$ years age groups with mean age of $14.5( \pm 0.87)$ years for urban and $15.32( \pm 0.96)$ years for rural schools respectively. Most of adolescent were from Hindu nuclear families (91.8\% urban and $85.8 \%$ rural). Parent's literacy in urban students was higher than the rural students.

It was a significant ( $\mathrm{p}$ value $<0.0001$ ) observation that urban students $(91.88 \%)$ missed more classes without permission than rural student $(41.67 \%)$. Involvements of the parents or guardian were found to be higher in the case of urban students than in case of rural students. Higher proportion of urban students reported that their parents or guardians checked to see that if their homework was done $(66 \% \mathrm{v} / \mathrm{s} 59 \%)$, understood their problem $(63.75 \% \mathrm{v} / \mathrm{s} 58.33 \%)$, and really knew their activities in their free time $(53.75 \% \mathrm{v} / \mathrm{s} 58.33 \%)$.

Mental health issues are higher among urban students than rural students however observation was not significant. Higher proportion of urban students felt lonely $(13.13 \% \mathrm{v} / \mathrm{s} \quad 10.00 \%)$ and worried about 
something that they could not sleep at night $(13.75 \% \mathrm{v} / \mathrm{s}$ $10.83 \%)$, they could not eat properly $(10.00 \% \mathrm{v} / \mathrm{s}$ $10.83 \%)$, and they hampered study or other work $(16.25 \% \mathrm{v} / \mathrm{s} 20.00 \%)$. It was a matter of high concern that serious consideration of attempting suicide during past twelve months was also found to be higher in the urban group $(9.30 \%)$ than the rural group $(6.6 \%)$.

Table 2: Issues on mental health.

\begin{tabular}{|c|c|c|c|}
\hline & \multicolumn{2}{|c|}{ Frequencies (\%) } & \multirow[b]{2}{*}{ P Value } \\
\hline & $\begin{array}{l}\text { Urban } \\
n=160\end{array}$ & $\begin{array}{l}\text { Rural } \\
n=120\end{array}$ & \\
\hline Felt lonely & $21(13.13 \%)$ & $12(10.00 \%)$ & 0.422233 \\
\hline $\begin{array}{l}\text { Worried } \\
\text { about } \\
\text { something } \\
\text { that they } \\
\text { could not } \\
\text { sleep at } \\
\text { night }\end{array}$ & $22(13.75 \%)$ & $13(10.83 \%)$ & 0.465209 \\
\hline $\begin{array}{l}\text { Worried } \\
\text { about } \\
\text { something } \\
\text { that they } \\
\text { could not } \\
\text { eat } \\
\text { properly }\end{array}$ & $16(10.00 \%)$ & $13(10.83 \%)$ & 0.820835 \\
\hline $\begin{array}{l}\text { Severe } \\
\text { worry } \\
\text { lasting } \\
\text { about two } \\
\text { week or } \\
\text { more } \\
\text { hampering } \\
\text { study or } \\
\text { other work }\end{array}$ & $26(16.25 \%)$ & $24(20.00 \%)$ & 0.417482 \\
\hline $\begin{array}{l}\text { Seriously } \\
\text { considered } \\
\text { attempting } \\
\text { suicide } \\
\text { past } 12 \\
\text { months }\end{array}$ & $15(9.30 \%)$ & $8(6.60 \%)$ & 0.414058 \\
\hline
\end{tabular}

Violence or bullying committed against urban students was significantly ( $\mathrm{p}$ value $<0.0001$ ) higher than that against rural students such as bullying $43.15 \% \mathrm{v} / \mathrm{s}$ $15.00 \%$, physical fights $(53.75 \% \mathrm{v} / \mathrm{s} 24.17 \%)$, and physical attack by family members $(43.13 \% \mathrm{v} / \mathrm{s} 15.83 \%)$ and by teachers $(51.25 \% \mathrm{v} / \mathrm{s} 11.67 \%)$.

\section{DISCUSSION}

In India only few studies have been conducted on similar issues. A study conducted among classes VIII-XII students of 10 government schools of Chandigarh showed that $13 \%$ students self-reported violent behaviors and $60 \%$ were engaged in physical fights at a frequency of more than once per week, comparable with the present study findings in urban school. ${ }^{6}$ In similar studies among adolescents in South Delhi almost $50 \%$ boys reported being involved in a physical fight and $15.8 \%$ reported having thought of attempting suicide in past 12 months. ${ }^{7,8}$ In compare to a similar study of urban and rural school students of Kolkata, our studies reported slightly less issues of mental health and physical factors while protective issues are slight less in urban students and slight higher in rural students.

Table 3: Issues on violence and bullying.

\begin{tabular}{|llll|}
\hline \multicolumn{4}{|c|}{ Frequencies (\%) } \\
& $\begin{array}{l}\text { Urban } \\
\mathrm{n}=160\end{array}$ & $\begin{array}{l}\text { Rural } \\
\mathrm{n}=120\end{array}$ & P Value \\
& & & \\
\hline $\begin{array}{l}\text { Physical } \\
\text { attacked by } \\
\text { family } \\
\text { members }\end{array}$ & $69(43.13 \%)$ & $19(15.83 \%)$ & $<0.0001$ \\
\hline $\begin{array}{l}\text { Physically } \\
\text { attacked by } \\
\text { teachers }\end{array}$ & $82(51.25 \%)$ & $14(11.67 \%)$ & $<0.0001$ \\
\hline $\begin{array}{l}\text { Physical } \\
\text { fight }\end{array}$ & $86(53.75 \%)$ & $29(24.17 \%)$ & $<0.0001$ \\
\hline Bullied & $69(43.15 \%)$ & $18(15.00 \%)$ & $<0.0001$ \\
\hline
\end{tabular}

GSHS have been conducted in different countries worldwide. The overall physical fight and bullying in the present study was somewhat higher than China study results. The prevalence of missing classes and mental health issues like self-reported loneliness and thought of attempting suicide were found in higher proportion in the study population than those in the national averages in China and Jordon. ${ }^{10}$

The study result showed that mental health and violence related issues were more among urban students in spite of having more protective factors than those in rural students suggesting the need of frequent teacher and parent's interaction ensuring supervision and monitoring of students, counseling and support of adolescents for development of a healthy school environment. These findings could not be applicable to all schools and all socioeconomic strata of communities. To get correct picture of mental health issues of adolescent more in depth studies for both sexes are required.

\section{ACKNOWLEDGEMENTS}

The authors would like to extend heartfelt thanks to followings for their continuous support and valuable suggestions to carry out the present study: Dr. Shalabh Sharma, Professor and Head of Department of Preventive \& Social Medicine, Ravindra Nath Tagore Medical College, Udaipur, Rajasthan, \& Dr. Rekha Bhatnagar, Senior Professor of Department of Preventive \& Social Medicine, Ravindra Nath Tagore Medical College, Udaipur, Rajasthan. 
Funding: No funding sources

Conflict of interest: None declared

Ethical approval: The study was approved by the Institutional Ethics Committee

\section{REFERENCES}

1. World health organization. Adolescent peer education in formal and non-formal settings. Report of and inter-country workshop, Monastir, Tunisia 69 December 2004. Cairo: WORLD Health Organization Regional Office for the Eastern Mediterranean; 2005. Available from: http://www.who.int/WHO-EM/WRH/042/E 03.05/500.pdf.

2. Eccles JS, Midgefield C, Wigfield A, Buchanan CM, Reuman D, Flannagan C,et al. development during adolescence : The impact of stage environment fit on young adolescents, experience in schools and in families. Am Psychol 1993; 48: 90101.

3. Kessler RC, Berglund $\mathrm{P}$, Demler $\mathrm{O}$, Jin R, Merikangas KR, Walters EE. Life time prevalence and age of onset distributions of DSM-IV disorders in the National Co -Morbidity Study Replication. Arch Gen Psychiatry. 2005;62:593-602.

4. Anti-Bullying Centre. School Bullying: Key Facts. Dublin: Trinity College; 2002. Available from: http://www.abc.tcd.ie/school.htm.

5. World Health Organization. Global school-based student health survey (GSHS). Available from: www.who.int/entity/chp/gshs/methodology/en/index .html.

6. Ray M, Malhi P. Adolescent violence exposure, gender issues and impact. Indian Pediatr. 2006;43:607-12.

7. Sharma R, Grover VL, Chaturvedi S. Suicidal behaviour amongst adolescent students in south Delhi. Indian J Community Med. 2008;33:85-8.

8. Sharma R, Grover VL, Chaturvedi S. Risk behaviors related to inter-personal Violence Among School and College-going Adolescents in South Delhi. Indian J Psychiatry. 2008;50:30-3.

9. Amrita Samanta, Shuvankar Mukherjee, Santanu Ghosh, Aparajita Dasgupta. Mental Health, Protective Factors and Violence among Male Adolescents: A Comparison between Urban and Rural School Students in West Bengal. Available from: http://www.ijph.in on Monday, September 14, 2015.

10. WHO GSHS country report. China global school based student health survey, 2003. Jordan global school based student health survey, 2004. http://www.who.int/entity/chp/gshs_jordan_report.p df

Cite this article as: Ahir R, Singhal Y, Dhaked M, Sharma P. A comparative study on protective factors, mental health and violence among male adolescents students of urban and rural school of Udaipur (Rajasthan), India. Int J Community Med Public Health 2015;2:421-4. 